\title{
当科における上腕骨近位端骨折の検討
}

\author{
福岡大学医学部整形外科 \\ 城 戸 正喜 - 竹下湮 \\ 榷藤 英資・柴田陽三 \\ 高岸直人
}

\section{Treatment of the Proximal Humeral Fractures}

by

\author{
M. Kido, M. Takeshita, E. Gondo, \\ Y. Shibata, N. Takagishi \\ Department of Orthopaedic Surgery, School of Medicine, \\ Fukuoka.University, Fukuoka Japan
}

Fractures of the upper end of the humerus are common and account for 4 to 5 per cent of all fractures.

Fourty-seven cases of this fracutres were treated in our clinic for the last seven years.

According to the concept of the Four-Segment classification (Neer's classification), the patients were classified into Minimal displacement (66\%), Two-part displacement (22\%), Three-part displacement (6\%) and Four-part displacement (6\%).

Relationship between the results of treatments and type of Neer's clvssification were analyzed in this study.

\section{はじめに}

上腕骨近位骨折は，全骨折の約 4〜5\%を占め，比 较的頻度の高い骨折である。 ての骨折に刘しては，解 剖的部位によるKocher の分類や，発生機転による Watson-Jones の 分類等が従来用いられてきた. Neer ${ }^{1)}$ (1970) は，上腕骨近位端を4つの主要な部位 に分けて分類した．我々は，Neer の分類が従来の分 類に比して治療法の選択決定やその予後を知る上で有 利と考えて，ての分類を用いて過去 7 年間に当科で加 療した 47 例について検討を加えたので報告する.

\section{対 象 症 例}

詔和 49 年 6 月より昭和 56 年 5 月までの過去 7 年間 飞当科飞抢いて加療した上腕骨近位端骨折は 47 例で ある.乙机らの症例を，Neer の分類を用いて分類し た（表 1 ).

乙の分類は，上脆筲近位端を骨頭，大結節，小結 節，骨幹の 4 つの主要な部位に分け，各々の部位が 1
表1 Neer の分類

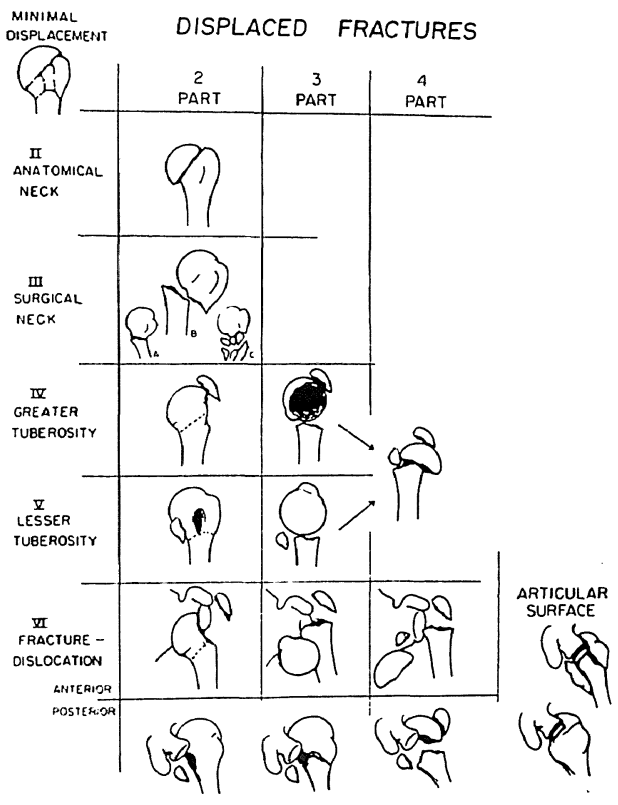


$\mathrm{cm}$ 以上の離開や， $45^{\circ}$ 以上の角度变形をむって枟位 があるとし，転位した部位より I〜VI型に分類した。 又, 転位した部位の数より Minimal displacement より Four part displacement の 4 つの Group に 分類している.

との分類に基づいて分類すると表 2 の如くなる. て れは, Neer ${ }^{2)}$ の報告に比して, Minimal displacement の比率が少なく, Articular Surface の骨折 は1例も経験しなかった。

\section{表 2}

\begin{tabular}{lcc} 
Minimal Displacement & $31(66 \%)$ & $(80 \%)$ \\
Two-Part Displacement & $10(22 \%)$ & $(10 \%)$ \\
Three-Part Displacement & $3(6 \%)$ & $(3 \%)$ \\
Four-Part Displacement & $3(6 \%)$ & $(4 \%)$ \\
Articular Surface Fractures & $0(0 \%)$ & $(3 \%)$ \\
\multicolumn{1}{c}{ Total } & 47 cases &
\end{tabular}

骨折は各年代層において発生し，その男女比は，男 20 例，女 27 例であった. 30 才から 50 才では，男 13 例，女 6 例で，乙の 19 例 中 11 例 が大結節骨折であ り，うち 6 例が大結節骨折を伴う肩関節脱曰であっ た. 次に，60才以上は，47 例中 18 例でありその男女 比は，男 3 例，女 15 例であり，加令に伴う骨腕弱に 比例して急激に增加する。

追跡期間は， 3 力月より 7 年 2 力月である. アンケ 一ト等の間接検竞は，47 例中 40 例飞可能であった。 評洒に際しては，教室高岸が提唱した試案に基づい $\tau$, 疼痛，機能，運動性，解剖，患者及び医師の評佂 の 5 項目について調べた，又，評佂不良例及び不満足 例については, 直接検執を行った.

\section{結果及び考察}

治療に扰いては，正確な 2 方向のX線撮影が不可欠 である事はいうまでむない，又，肩関節の機能再獲得 を主目的に置くべきである.

1. Minimal displacement

約 $66 \%$ が整復を必要としないとの Group に属し た。この Group の骨折は, 各部位が腱㤆や骨膜で集 合された状態であるので，三角巾，デゾ包帯固定で疼 痛が消退しだい，運動療法を行って満足出来る結果を 得た. 又, 大結節骨折を伴う肩関節脱臼，6 例中 2 例
に腱板断裂を認めた．Neviaser は，この脱臼骨折に おいては，縱断裂を含めて腱板䉼裂が必発であると報 告している. 仙石ら ${ }^{3)}$ は, 整復 3 週後に肩関節造影を 施行し， $25 \%$ に腱板断裂を認めている，骨伤のみなら ず，健板損伤に対してむ充分な配虑が必要と考える.

2. Two part displacement

一部位のみが転位している骨折である。この Group においては, 骨頭罗死の発生頻度の高い解剖頸部骨 折，腱板付着部の大結節骨折が観血的療法の適応とな る. このうち, 外科頸骨折に対しては, 徒手整復後 Hanging Cast を, 整復不能例においては, Zero position への持続竞引にて，ほぼ満足し得る結果を 得ているが，2例において，上腕二頭笳長頭健が介在 したための整復不能例を経験した

症例 $2: 14$ 才, 男.

整復操作において，整復位を得る事が出来ず，関節 造影に扔いて結節間裂に，上腕二頭筋長頭腱を認めな い，観血的に近位骨片之骨幹部の間に介在していた長 頭腱を正常な位置に戻し，骨接合術を施行．受傷 6 力 月後, 肩関節可動域は正常で，日常生活動作等におい て何の障害むない。

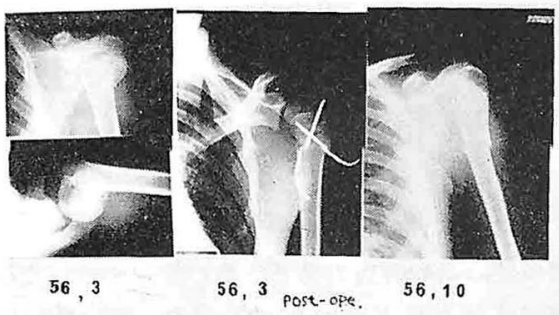

Case. 2. 14 y.o. M

図 1 症 例 2

3. Three part displacement

この Group の骨折は，忶位のある外科頸骨折に， 大小結節のいずれかの恒位を伴ったものである．当科 で加療した症例は，3例である．うち2 例が脱臼骨折 であり，てれに対しては，観血的に整復を㸡行後，骨 接合術を行った。

4. Four part displacement

主要な 4 つの部位が，全て枟位した骨折で，骨頭壇 死の発生頻度の高い骨折である。

Watson Jones の分類における Impacted frac- 
ture dislocation は, この Group に位置づけられ る.

Neer は自例 19 例を分析し, 保存的に加療した 7 例, 内固定 5 例に抢いては良い結果が得られず，人工 骨頭置換術の 7 例が良い結果を得た之報告し，人工骨 頭置撸術を推奖している. 又, 遠藤らはZero position 方向への持続举引による保存的療法にて良い結 果を報告している.

我々は, 人工骨頭置換術 2 例, 持続牽引法 1 例を経 験した. 結果之して 3 例と屯満足し得る結果を得る事 が出来ず，令後とも検討を加えてゆくつむりである.

症例 $4: 45$ 才, 女, 理容師

受傷後 7 日目に人工骨頭置換術を施行. 調查時, 肩 外転 $80^{\circ}$, 外旋 $10^{\circ}$ であり, 評洒は不可である. 患者 の意欲, 後療法に特に問題があったと思われる症例で ある.

$$
\text { ま と め }
$$

1. 過去 7 年間に当科で加療した上腕骨近位端骨折 47 例について，Neer が提唱した分類を用いて分析 した.

2. 47 例中 31 例（約 $66 \%$ ) が転位のない骨折で, 三角布等の簡単な固定法で良い結果を得た。

3. Two part displacement の 10 例中 2 例にお いて上腕骨二頭長頭腱が介在の為, 観血的整復を必要

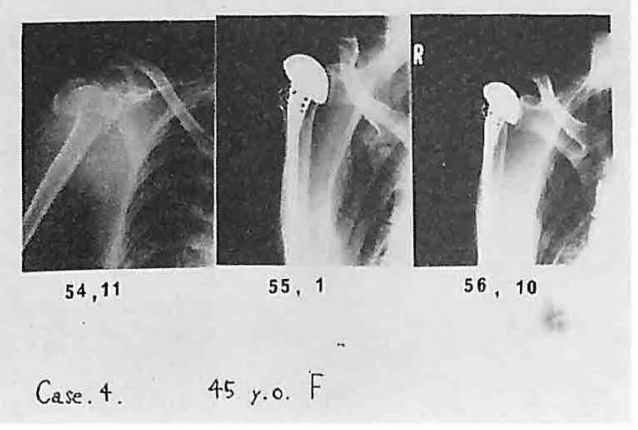

図 2 症例 4

とした.

4. Four part displacement においては, 全例 良い結果が得られず，今後と屯㭲討して行く必要があ る.

参考文 献

1）宮城成圭：災㕩医学，16：379，1973.

2) Neer II, C. S.: J. Bone Joint Surg., 52-A: 1077, 1970.

3) Neer II, C. S.: Fractures and Dislocation of the Shoulders, Rockwood Green, Fractures. 585, Lippincott, Philadelpia, 1975.

4) 折原正美：整形外科 Mook, 16:140, 1980.

5) 仙石裕美: 整形- 災害外科, 23 (No. 10): 1153, 1980. 